\title{
Reconstructing the authenticity of place
}

\author{
Sharon Zukin
}

Published online: 9 January 2011

(C) The Author(s) 2011. This article is published with open access at Springerlink.com

\begin{abstract}
Sociologists tend to over-conceptualize the divergent cultures of adjacent places, both neglecting necessary structural and institutional factors and focusing on symbols more than interests. In the post-industrial era, sense of place reflects geographical mobility, the social construction of landscape, and marketing strategies. Like gentrified neighborhoods and hipster districts in cities, rural regions like Vermont are reborn through the social, cultural, and economic efforts of local entrepreneurs to create a distinctive and authentic sense of place.
\end{abstract}

Keywords Gentrification · Rural gentrification · Authentic place

Long before sociologists began to worry about developing an analytic framework to explain differences in local character, literary travelers wrote about the unusual cultural practices of men and women whom they met in distant places. Essayists like Michel de Montaigne speculated on what causes these cultural differences. Is it "hard" factors like climate and geography? Or is it "soft" factors like culture that shape accumulated practices into the enduring - or perhaps not so enduringauthenticity of place?

Jason Kaufman and Matthew Kaliner's fascinating article about differences between the adjacent states of Vermont and New Hampshire renews the literary travelers' tradition of wondering what makes people who live so close to each other so different in politics, style, and self-expression. They say, and Harvey Molotch comments on this in his response, that history repeats itself until it doesn't; cultural distinctiveness works in many ways; and borders matter. I would take a step back, though, to emphasize three necessary and sufficient factors that create both a structural and an institutional base for modern settlements to develop distinctive, contrasting cultures. First and most obvious, individuals must be free to exercise 
choice in where they live. Second, there must be a local history that exerts appeal to outsiders through the social construction of either a material or a symbolic landscape. Third, local entrepreneurs must use a marketing strategy that emphasizes some elements of this landscape while suppressing others. (These elements may also be made obsolete or powerless by external factors). Only under these conditions do native-born residents and newcomers engage in the reflexive creation of a spatial habitus.

A market in land and geographical mobility are almost too obvious to claim as causal factors in the reshaping of twentieth century New England. But if we think about other regions of the world and earlier eras, it is sensible to make this point explicit. Do we wonder why, in areas where few newcomers settle among traditional populations, adjacent regions like Normandy and Brittany are not alike? Do we wonder why, despite the emergence of a market economy in recent years, Chinese provinces have neither refined nor reinforced cultural differences so that some regions would attract new groups of highly educated migrants while their neighbors would not? Cities in general lure both upscale and downscale migrants. But even in Shanghai, real estate markets have just begun to accumulate so many different kinds of amenities that adjacent neighborhoods develop, or reassert, a completely different sense of place (Zhang 2009). When men and women are able to leave their birthplace and move freely among neighborhoods and regions, their cultural choices are shaped by and in turn help to shape property markets.

British geographers have been aware of the growing importance of selective migration into rural areas at least since the 1980s (e.g., Cloke and Thrift 1987, 1998). They have written about "class colonization and lifestyle strategies" that recreate an authentic sense of place while challenging and sometimes displacing longtime residents. North American geographers and anthropologists have also looked at "rural gentrification" in Western states where new, highly educated migrants who want to live in beautiful, "natural" landscapes create alliances with large landowners and real estate developers to outlaw longstanding economic activities like mining that encroach upon their vision (Ghose 2004; Hines 2004). There is, then, a necessary marriage of convenience between profit-oriented place entrepreneurs, as Logan and Molotch (1986) call them, and culturally dominant newcomers.

This union creates a discourse - maybe a literature or maybe just a marketing campaign - that "brands" a region in a specific way. A powerful discourse becomes a rhetoric and then a strategy of growth, shaping new zoning (and other) laws that ban chain stores, or mandate very small stores, or require preservation of "historic" buildings, or forbid smokestacks and commercial fishing, all of which reinforces a specific kind of landscape that will likely attract more newcomers who share these tastes. Ski resorts like Stowe, Vermont, and Park City, Utah, have learned to create new value from the infrastructure of the past, building condos and chalets for affluent, part-time new residents on the outskirts while preserving the small town look and feel of the center.

These makeovers do not always work; sometimes, as in New Hampshire, they are not even attempted. The less diversified a local economy, the less likely it is that local people will unite around an alternative scenario for future growth. Whether vested interests or ideologies prevent them from engaging a new narrative of place, 
or a lack of connectedness through social networks prevents them from taking action, business and political leaders in the former steel town of Youngstown, Ohio, have been less likely than their counterparts in the steel town of Allentown, Pennsylvania, to create a new image of place that would attract new investors and residents (Safford 2009).

In Allentown, industrial elites thought about replacing steel mills with other economic activities for decades. Colleges and universities, including a branch of the state university, were located nearby. While the city attracted a number of high tech companies, it also had qualities that would encourage highly educated migrants to settle down. These included both a downtown residential district with historic architecture - the embodiment of a place's symbolic capital - and modern suburbs with good schools. Allentown is located, moreover, within long but tolerable commuting distance from New York and Philadelphia, metropolitan regions with a broad range of jobs. These structural advantages were not available to reshape local character in Youngstown.

Neither were most of them available in Bethlehem, the adjacent city to Allentown in the Lehigh Valley, which could play New Hampshire to Allentown's Vermont. Bethlehem Steel Corporation, the largest property owner in town, carried out an environmental cleanup that enabled them to sell the land and buildings to the Sands Casino of Las Vegas for an East Coast branch. The conversion from blast furnaces to slot machines aroused a great deal of opposition, especially on the working-class south side of the city, an area that resembled Youngstown.

By the same token, in contrast to the neighboring town of Lawrence, the old industrial city of Lowell, Massachusetts, re-created itself during the 1980s by priming the pump of both public and private funds for high-tech growth, especially in computers, and turning its historic textile mills into the first urban park in the National Parks System. But Lowell declined in the next decade. Having moved from dependence on one industry, textiles, to dependence on another industry, computers, and on one firm in that industry, Wang Laboratories, Lowell was not able to sustain its new chosen path when Wang's business declined (Gittell and Flynn 1995). Comparing Youngstown and Allentown, Allentown and Bethlehem, or Lawrence and Lowell raises questions about which structural and institutional factors play the most important role in reshaping local character, and for how long.

When we look at the smaller scale of areas within cities, the reverse images of Vermont and New Hampshire look very familiar as a gentrification narrative. Declining neighborhoods that are reborn as either gentrified or hipster districts reflect an initial choice by men and women to move to, or remain in, the city, which is often interpreted as a lifestyle choice though it is also a response to opportunities for work and access to social and cultural networks (Lloyd 2006). Also crucial but rarely acknowledged is the entrepreneurial role of newcomers who open businesses in the district - art galleries, performance spaces, restaurants, boutiques, and barsthat not only provide spaces of consumption for residents and visitors to develop a lifestyle, but also provide visible opportunities for neighborhoods to develop a new place identity. In New York City, both the recent gentrification of Harlem and the slightly earlier emergence of Williamsburg, an industrial neighborhood on the Brooklyn waterfront, as an artists' and hipsters' district reflect the importance of new retail entrepreneurs who reshape local character (Zukin et al. 2009). By catering to 
their own community, these entrepreneurs develop a new place identity. In Williamsburg, new residents opened "edgy" performance spaces, art galleries, ethnic restaurants, and alternative music bars that catered to their friends' tastes as well as those of visitors. In Harlem, though, new retail businesses were more in the mainstream, often with a multicultural or pan-African theme, and included branches of global chains. Most important, an enterprise zone offered subsidies to many stores to locate in Harlem, raising questions about the role of the local, state, and federal government in creating a sense of place.

Although a new place identity may play off elements of the area's past - and present itself as respectful of the community's authenticity-social and cultural networks of new producers and consumers create, nurture, and often capitalize on a completely new sense of place (Zukin 2010). Harlem's new retail entrepreneurs claim they hark back to the Harlem Renaissance, the golden age of artistic, literary, and political innovation in the 1920s and 1930s. In fact, they modernize and commercialize Harlem to make it more like the Upper East and Upper West Sides. Williamsburg's creative entrepreneurs nurture what they see as the area's gritty authenticity, only to risk displacement by high rents and real estate development.

Will this be the logical end of the social construction of terroir in Vermont, where the symbolic capital of place is restructured to attract financial capital? New farms, many of them engaged in organic growing practices, are gradually recreating a regional agriculture and dairy industry (Trubek 2008). In contrast to the past, this time farmers, schools, and nonprofit organizations seek economic value from the Vermont "brand." Directly or not, they are self-conscious entrepreneurs of place.

So where's the mystery? In cities or in rural areas, we can only understand the divergent paths of adjacent places by examining both cultural strategies and economic motives. If this leads to paired case studies of the Dakotas and the Carolinas, let's keep both economy and culture in mind.

Open Access This article is distributed under the terms of the Creative Commons Attribution Noncommercial License which permits any noncommercial use, distribution, and reproduction in any medium, provided the original author(s) and source are credited.

\section{References}

Cloke, P., \& Thrift, N. (1987). Intra-class conflict in rural areas. Journal of Rural Studies, 3, 321-333. Cloke, P., \& Thrift, N. (1998). Class colonisation and lifestyle strategies in Gower. In P. J. Boyle \& K. H. Halfacree (Eds.), Migration into rural areas: Theories and issues. Chichester: Wiley.

Ghose, R. (2004). Big sky or big sprawl? Rural gentrification and the changing rural landscape of Missoula, Montana. Rural Geography, 25(6), 528-549.

Gittell, R. J., \& Flynn, P. M. (1995). The Lowell high-tech success story: what went wrong? New England Economic Review, 57-70

Hines, J. D. (2004). Moving back to modernity: Urban-to-rural migration and the cultural dialectic of authenticity and progress. Ph.D. dissertation, University of California-Santa Barbara.

Lloyd, R. (2006). Neo-Bohemia: Art and commerce in the post-industrial city. New York: Routledge. 
Logan, J., \& Molotch, H. (1986). Urban fortunes. Berkeley and Los Angeles: University of California Press.

Safford, S. (2009). Why the garden club couldn't save Youngstown: the transformation of the Rust Belt. Cambridge: Harvard University Press.

Trubek, A. B. (2008). The taste of place: A cultural journey into terroir. Berkeley and Los Angeles: University of California Press.

Zhang, T. (2009). Striving to be a global city from below: The restructuring of Shanghai's urban districts. In X. Chen (Ed.), Shanghai rising: State power and local transformations in a global megacity. Minneapolis: University of Minnesota Press.

Zukin, S. (2010). Naked city: The death and life of authentic urban places. New York: Oxford University Press.

Zukin, S., et al. (2009). New retail capital and neighborhood change: boutiques and gentrification in New York City. City and Community, 8(1), 47-64.

Sharon Zukin teaches Sociology at Brooklyn College and the City University Graduate School. She writes about cities, most recently in Naked City: The Death and Life of Authentic Urban Places (Oxford University Press, 2010), and consumer culture (Point of Purchase: How Shopping Changed American Culture, Routledge, 2004). 